\title{
Brief Communication Thombotic Trombocytopenic Purpura: Allergic Reaction to Plasma Proteins During Therapeutic Apheresis
}

\author{
Max Mendez-López ${ }^{1,2}$; XiniaRojas ${ }^{1}$; Hever Herrera ${ }^{1}$. \\ ${ }^{I}$ Blood Bank and Transfusion Medicine Service. Hospital México, San José, Costa Rica. \\ ${ }^{2}$ HematologyDepartment. Hospital Calderón Guardia. San José, Costa Rica.
}

\begin{abstract}
Thrombotic Thrombocytopenic Purpura (TTP) is a raredisordercharacterized by microangiopathichemolysiswiththrombosis. The golds tandard of treatment is the rapeutic plasma exchangewhichreplenishesthedepleted ADAMTS-13. Herewepresent a rarecomplication: a patient that developed allergy to plasma proteins and remitted afterapheresis with albumin.
\end{abstract}

Keywords:ThromboticThrombocytopenic Purpura, AllergytoPlasma Proteins, Plasma Exchange.

\section{INTRODUCTION}

ThromboticMicroangiopathy refers to a group of diseases in whichthehallmarkisthepresence of microvasculopathywithorwithoutthrombosis ${ }^{1,2}$. Thrombotic Trombocytopenic Purpura (TTP) isanexample of thesedisorders. Itisdefined by thepentad of microangiopathichaemolyticanaemia, trombocitopenia, neurologicalsymptoms, renal disorders and fever'; however, itiswidelyacceptedthatonlythefirsttwocriteriaare neededtofulfilldiagnosis.Neurologicalsymptoms and feverrepresent late events and maydelay interventions ${ }^{4}$, therefore, plasma exchangemust be startedimmediately in ordertodecreasemortalityratesfrom $90 \%$ to $10 \%{ }^{3-6}$. Becauseof itsbroadclinicalpresentation, theterm TTP-HaemolyticUremicSyndrome (TTP-HUS) wascreatedtorefertothisgroup of conditions ${ }^{2,4}$. The firstinsightintothepathogenesis of TTP waspublished by Moake in 1982, whofoundthatpatientswithrelapsingcongenital TTP hadunusuallylarge von Willebrand Factor (vWF) multimerswhile in remission, a findingthatwasnotpresent in healthypeople. In 1997, Furlan and coworkersdemonstratedthatdeficiency in the activity of the vWF-cleaving protease ADAMTS-13 was the cause of chronic relapsing TTP ${ }^{8}$, defining HUS and TTP as different clinical entities, the latter

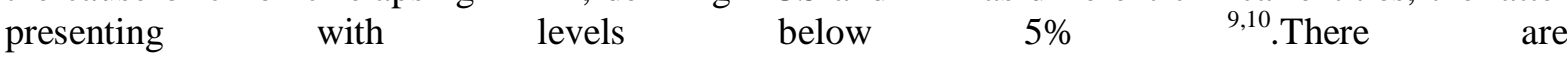
fourdifferentpathophysiologicalmechanismsthatexplainfindings in thromboticmicroangiopaties: vWFplateletaggregates in ADAMTS-13 deficiency, microangiopathy in autoinmune and infectious TTP, tumor cellsthrombosisand fibrin-plateletthrombi in DisseminatedIntravascularCoagulation ${ }^{10}$.Despitetheautoimmune ${ }^{10}$ or genetic ${ }^{11}$ aetiology, thegoldstandard of treatmentistherapeutic plasma exchange (TPE), whichremovestheinhibitors and replenishesthedeficient ADAMTS-13 ${ }^{12,13}$. Herewedescribe a case ofa patientwithPTT whodevelopedanacuteallergicreactionto plasma proteinsduringTPE.

\section{Case Report}

A femalepatient of 32 yearsoldwith no important prior medical historyvisitedherprimarycarephysicianforupperlimbshaematomaswithpetechiaealongthethorax and abdomen thatstarteddevelopingin theprevious10 days. Shedeniedheadaches, visual disturbancesoranyneurologicalsymptoms. Shehad no history of recent trauma and wasnottakingmedications. Therewerenosigns of bleeding, no splenomegaly and therest of thephysicalexaminationwas normal. Bloodsamplesshoweda normocyticnormochromicanaemiawith $7.5 \mathrm{~g} / \mathrm{dL}$ of haemoglobin, normal leukocytecount, 15.000 platelets $/ \mathrm{mm}^{3}$ and normal coagulationtests. Withtheseresultsshewasreferredtothenearesthaematologydepartment, whereperipheralbloodmorpholog yexaminationdemonstratedschizocytes and polychromasia. ThromboticThrombocytopenic Purpura 
wasdiagnosed and the patientinforme dabouttherapeuticplasmapheresis, whichstartedimmediately. Lactatedehydrogenase (LDH)levelwas 532U/L, withfibrinogen in $858 \mathrm{mg} / \mathrm{dl}$ andnormalrenal functiontests. Thirtyeight minutes afterthefirstsession of plasma exchangeshedevelopedplasma proteinsallergymanifested as generalized cutaneous rashandpruritus. At thatmomentshedidnotpresentbronchospasm, theproceducewas suspended and a fall in plateletsweredocumentedlateronthesameday (Table 1). Because of thisscenariosteroidswereaddedto a dose of $1 \mathrm{mg} / \mathrm{kg} /$ day and therapeuticapheresiswasrestartedwith $5 \%$ albuminthenextmorning. No response wasseenwiththefirstsessionas plateletscontinuedtodescendto $8.000 / \mathrm{mm}^{3}$.ADAMTS-13 activitylevelstakenonadmissionwere $0.5 \%$. Five consecutive a pheres is procedures were completed and eventuallyallsigns of TTP disappeared. Beforedischarge, ADAMTS-13 activitylevelreturnedto 90\%.Untilnow, 8monthslater, she has notrelapsed.

\section{Discussion}

The

clinicalpresentation

of

TTP maydiffer ${ }^{14}$ butitremainsunknownwhetherornotthisvariabilityrepresent a prognosticfactor. Plasmapheresisrelated adverse eventshavebeenreportedto be as low as $1.6 \%$, however, informationregardingtheincidence of allergicreactionsduring TPEfor TTP islimited ${ }^{16,17}$. Interestingly, ourpatienthada severe ADAMTS-13 deficiency, whichcorrelateswithvWFdependentmicrovascular trombosis ${ }^{18}$, and despite no specificreplacementtherapywasgivenforthedeficientprotease, ADAMTS13 levelsreturnedto normalwithalbumin TPE, suggestingthatanimmunologicallymediatedmechanismwas corrected ${ }^{13}$.In this case TTPmay be anearlypresentationof other disease, however,severe ADAMTS-13 deficiencyisextremelyrare in patientswithsecondary TTP ${ }^{12,18}$. Itisalsoquestionablethatsteroidscouldhavehadanyimmediatebeneficial effect in thispatient as ithas notbeenestablishedthattheir useshortentheduration of plasma exchangetherapy ${ }^{19}$. Informationregardingtheoptimaltreatment of plasma-proteinallergicpatientsislimited; someauthorshavedemonstratedthatweeklyinfusions of Rituximab are effective in theacuterefractorypatients ${ }^{20}$ butaccesstothisdrugmay be difficult in developingcountries. No data isavailablethatcompares directlyrituximabto $\quad$ TPE in thisscenariobutconsideringthefewavailableinformation, the use of TPE withalbuminmay be a safealternative in patientswithallergicreactions in situationswhereotheralternatives are limited.

\section{REFERENCES}

[1] Vesely SK, George JN, Lämmle B, Studt JD, Albeiro L, El-Harake MA et al. ADAMTS13 activity in thrombotic thrombocytopenic purpura-hemolytic syndrome: relation to presenting features and clinical outcomes in a prospective cohort of 142 patients. Blood 2003;102:60-8.

[2] Taylor CM, Chua C, Howie AJ, Risdon RA; British Association for Paediatric Nephrology. Clinico-pathological findings in diarrhoea negative haemolytic uraemic syndrome. PediatrNephrol 2004;19:419-425

[3] Amorosi EL, Ultmann JE. Thrombotic thrombocytopenic purpura: report of 16 cases and review of the literature. Medicine 1966;45:139-59.

[4] Sadler JE. Von Willebrand Factor, ADAMTS 13 and thrombotic thrombocytopenic purpura. Blood 2008;112:11-18

[5] Rock GA, Shumak KH, Buskard NA, Blanchette VS, Kelton JG, Nair RC et al. Comparison of plasma exchange with plasma infusion in the treatment of thrombotic thrombocytopenic purpura: Canadian Apheresis Study Group.NEngl J Med 1991;325:393-397

[6] Hayward CP, Sutton DMC, Carter WH Jr, Campbell ED, Scott JG, Francombe WH et al. Treatment outcomes in patients with adult thrombotic thrombocytopenic purpura-hemolytic uremic syndrome. Arch Intern Med 1994;154:982-7

[7] Moake JL, Rudy CK, Troll JH, Weinstein MJ, Colannino NM, Azocar J et al. Unusually large plasma factor VIII:von Willebrand factor multimers in chronic relapsing thrombotic thrombocytopenic purpura. N Engl J Med 1982;307:1432-1435.

[8] Furlan M, Robles R, Solenthaler M, Wassmer M, Sandoz P, Lämmle B. Deficient activity of von Willebrand factor-cleaving protease in chronic relapsing thrombotic thrombocytopenic purpura. Blood. 1997;89:3097-3103.

[9] Moake JL. Thrombotic microangiopathies. N EnglJMed 2002;347: 589-600.

[10] Tsai HM. Autoimmune Thrombotic Microangiopathy: Advances in Pathogenesis, Diagnosis, and Management SeminThrombHemost 2012, 38(5):469-82

[11] Levy GG, NicholsWC, LianEC,Foroud T, McClintick JN, McGee BM et al. Mutations in a member of the ADAMTS gene family cause thrombotic thrombocytopenic purpura. Nature 2001;413(6855):488-49

[12] Szczepiorkowski ZM, Winters JL, Bandarenko N, Kim HC, Linenberger ML, Marques MB et al. Apheresis Applications Committee of the American Society for Apheresis. Guidelines on the use of therapeutic apheresis in clinical practice--evidencebased approach from the Apheresis Applications Committee of the American Society for Apheresis. J Clin Apheresis 2010;25:83-177.

[13] Michael M, Elliot EJ, Ridley GF, Hodson EM, Craig JC. Interventions for haemolytic uraemic syndrome and thrombotic thrombocytopenic purpura. Cochrane Database Syst Rev 2009 Jan 21;(1):CD003595.

[14] Sarode R. Atypical Presentations of Thrombotic ThormbocytopenicPurpura: A Review. J Clin Apheresis 2009; 24:47-52

[15] Ziselman E, Bongiovanni M, Wurzel H. The Complications of Therapeutic Plasma Exchange. Vox Sang 1984; 46:270-276 
[16] Norda R, Berséus O, Stegmayr B. Adverse events and problems in therapeutic hemapheresis.A report from the Swedish registry. Transfusion and Apheresis Science 2001; 1:33-41

[17] Sutton DM, Nair RC, Rock G and The Canadian Apheresis Thrombosis Group. Complications of Plasma Exchange. Transfusion 1989;29:124-127

[18] Sadler EJ. Von Willebrand Factor, ADAMTS13 and Thrombotic Thrombocytopenic Purpura. Blood 2008;112:11-18

[19] Cataland SR, Jin M, Ferketich AK, Kennedy MS, Kraut EH, George JN et al. An evaluation of cyclosporine and corticosteroids individually as adjuncts to plasma exchange in the treatment of thrombotic thrombocytopenic purpura. Br J Haematol 2007; 136:146-149

[20] Scully M. Rituximab in the treatment of TTP. Hematology 2012; 17 Suppl 1:S22-4

TABLE 1. Laboratory evaluation

\begin{tabular}{|l|c|c|c|}
\hline & Day Before TPE & Day of TPE & After5 sessions of Albumin TPE \\
\hline Hemoglobin $(\mathrm{g} / \mathrm{dL})$ & 7.5 & 6.8 & 9.9 \\
\hline Platelets $\left(\mathrm{x} \mathrm{mm}^{3}\right)$ & 15.000 & 10.000 & 247.000 \\
\hline LDH $(\mathrm{UI} / \mathrm{L})$ & 532 & 760 & 121 \\
\hline PeripheralBloodSmear & $\begin{array}{c}\text { Schizocytes }+ \\
\text { Polycromasia }+\end{array}$ & $\begin{array}{c}\text { Schizocytes }+ \\
\text { Polycromasia }++\end{array}$ & No Schizocytes \\
\hline
\end{tabular}

\section{LDH: Lactate Dehydrogenase}

